\title{
Working
}

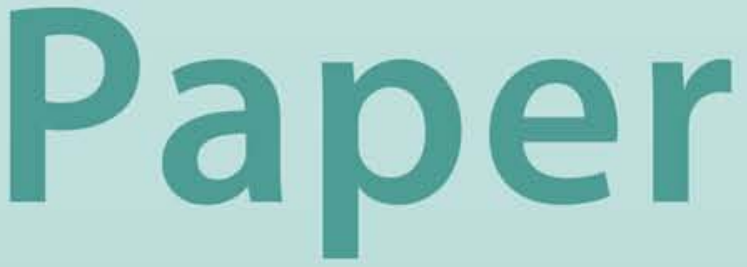


Evidence on Productivity, Comparative Advantage, and Networks in the Export Performance of Firms

Luca Antonio Ricci and Federico Trionfetti 


\title{
IMF Working Paper
}

Research Department

\section{Evidence on Productivity, Comparative Advantage, and Networks in the Export Performance of Firms}

\section{Prepared by Luca Antonio Ricci and Federico Trionfetti}

Authorized for distribution by Andrew Berg

April 2011

\begin{abstract}
This paper tests the effect of comparative advantage, size, and networking on the firm probability of exporting. The closest theoretical framework is the one of Bernard, Redding, and Schott (2007), with firm heterogeneity across countries and industries. We use a recently assembled multi-country multi-industry firm level dataset, and construct original measures of comparative advantage. The results show that firms are more likely to export if they belong to the comparative advantage industry, if they enjoy a higher productivity, or if they benefit from foreign, domestic, or communication networks.
\end{abstract}

JEL Classification Numbers:F11, F12, F14, L14

Keywords: Heckscher-Ohlin, comparative advantage, new-new trade theory, productivity, firms’ export probability, networks

Author’s E-Mail Address:LRicci@imf.org and Federico.Trionfetti@univmed.fr

\section{This Working Paper should not be reported as representing the views of the IMF.} The views expressed in this Working Paper are those of the author(s) and do not necessarily represent those of the IMF or IMF policy. Working Papers describe research in progress by the author(s) and are published to elicit comments and to further debate. 


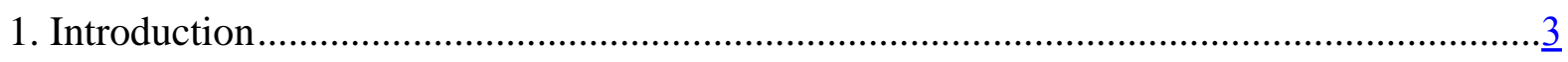

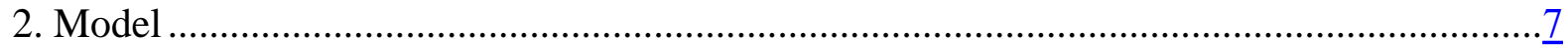

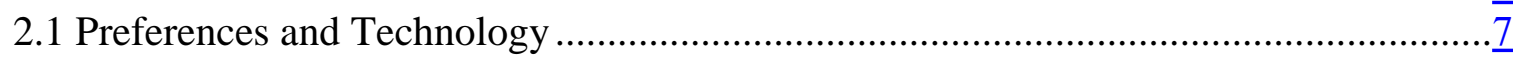

2.2 Prices, Revenues, and Profits................................................................................

2.3 Equilibrium and Aggregation ................................................................................ 11

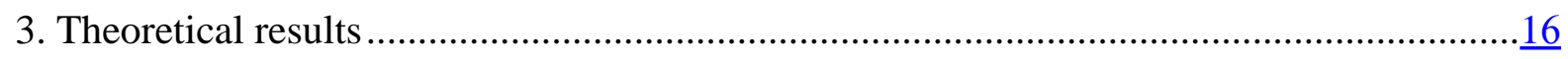

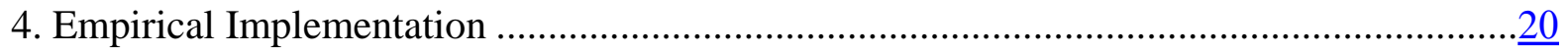

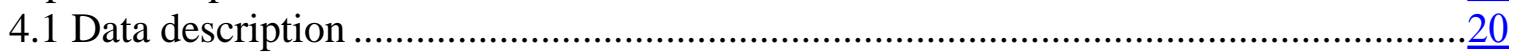

4.2 Empirical specification ....................................................................................2

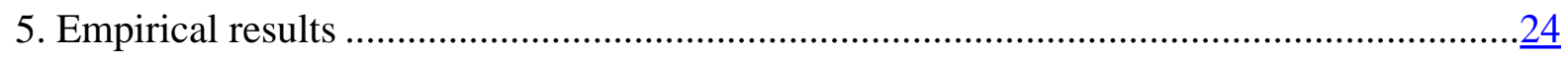

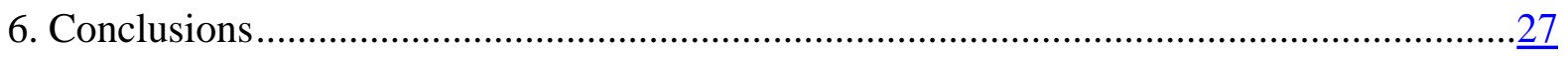

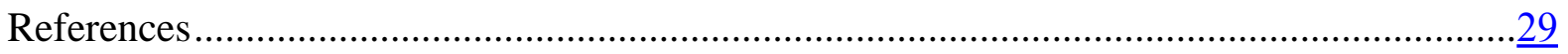

Tables

Table 1. Percentage of Firms that Exports by Country........................................................

Table 2. Percentage of Firms that Exports by Industry …………………………………...

Table 3. The Effect of Comparative Advantage and Productivity on the Probability of

Export …….................................................................................................................

Table 4. The Effect of Comparative Advantage and Productivity on the Probability of

Export ..........................................................................................................................

Table 5. The Effect of Comparative Advantage, Productivity, and Networks on the Probability of Exporting ..................................................................................................

Table 6. The Effect of Comparative Advantage, Productivity, and Networks on the

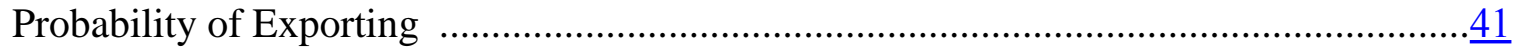

Figures

Figure 1. Capital/Labor Ratio by Country ……………………………………….... $\frac{37}{38}$

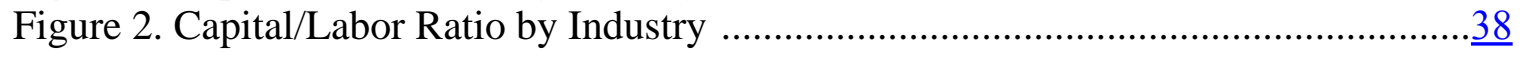

Appendix Tables

Summary Statistics 


\section{Introduction}

Recent theoretical developments in trade theory and the availability of firms level data has generated an intense research agenda on the exporting behavior of firms. ${ }^{1}$ Even a cursory glance at the data reveals that not all firms are engaged in international trade. This diversified reality about the export performance of firms has found a theoretical collocation in general equilibrium models in a recent literature initiated by Bernard, Eaton, Jensen, and Kortum (2003) and Melitz (2003) and whose principal characteristic is that firms differ in productivity. In Melitz' work, the presence of a fix export cost generates endogenously a partition of producing firms into exporting and non-exporting firms where only the most productive firms find it profitable to export. His model has opened the way to a rich and fast-growing literature which features firms heterogeneity. One such development is proposed by Bernard, Redding, and Schott (2007) who have build a model that integrates the Heckscher-Ohlin model of comparative advantage with Melitz heterogenous firms model. An implication of their model is that, under some conditions, the probability of exporting is higher in the industry of comparative advantage. Another strand of literature has highlighted the role of networking connections in reducing the effect of informational barriers, thereby

\footnotetext{
${ }^{1}$ For an extensive survey of the empirical work, see Wagner (2007).
} 
enhancing firms' export performance; see, e.g., Rauch (2001), Casella and Rauch (2002).

Overall, the theoretical literature recalled above predicts that the probability of exporting is influenced by productivity, comparative advantage, and networking. In the present paper we subject these three predictions to empirical verification using firm-level data from a survey compiled by the World Bank and covering a large group of developing countries and several sectors. Very few studies undertake an assessment of firms export performance using firm-level data from many countries and sectors. ${ }^{2}$

We contribute to the literature in three ways. Our principal contribution is to offer a novel way of testing empirically the relevance of the HeckscherOhlin model. Existing verifications of this model are based on the factor content of trade approach, or use the discriminating criteria offered by the home market effect, or leverage on the prediction on the production pattern. ${ }^{3}$ Yet, even the most recent and innovative works have not directly related the probability of exporting to the presence of comparative advantage. A hint that the comparative advantage influences the probability of exporting appears in a descriptive statistics based on U.S. data provided by Bernard,

\footnotetext{
${ }^{2}$ For a recent example, see Barba Navaretti et al. (2010).

${ }^{3}$ See for instance Leamer (1980), Trefler $(1993,1995)$, and Davis and Weinstein (2001) for the first approach; Davis and Weinstein (2003), Head and Ries (2001) and Hanson and Xiang (2004) for the second approach; and Romalis (2004) for the third.
} 
Jensen, Redding, and Schott (2007, Table2). They show that in industries where the U.S. is likely to have a comparative advantage the percentage of firms who export is higher than in other industries. We provide a systematic investigation on this relationship. We indeed find a positive relation between comparative advantage and export performance of firms.

Another striking result of our empirical analysis is the importance of networks for firms export performance. The role of networks in facilitating international trade has been discussed extensively. Anecdotal evidence, theoretical models and empirical evidence can be found in the works of Rodrick (2000), Rauch (2001), Casella and Rauch (2002), Rauch and Trindade (2002), Wagner, Head, and Ries (2002), Rauch and Casella (2003), Combes, Lafourcade and Mayer (2005), and in the context of development in Hausmann et al. (2007) and Hidalgo et al. (2007). Networks and connections reduce the disadvantage presented by informational barriers, and hence reduce the cost of economic transactions. In line with this literature, we find that firms are more likely to export if they benefit from positive spillover from foreign networks (financial linkages, joint ventures, foreign ownership), communication networks (E-mail, web site), and domestic networks (chamber of commerce, regulation). Firms bear instead a lower probability of exporting if they are affected by state or labor networks (public control and unionization).

Finally, our results also confirm that the probability of exporting is in- 
creasing with productivity, a fact that is by now well documented in many studies which often employ firm sales as a proxy for productivity. Evidence in this sense is found inter alia in Aitken, Hanson and Harrison (1997), Roberts and Tybout (1997), and Bernard and Jensen (1999, 2004). A different, though related, strand of literature has verified the empirical validity of Melitz (2003) model and its implications; e.g. Hanson and Xiang (2008), Helpman, Melitz and Rubinstein (2008), Eaton, Kortum, and Kramarz (2008), Chaney (2008), and Crozet and Koenig (2010). In all these works, firms productivity is a key element in determining the outcome (trade flows, intensive and extensive margin, etc.), but none of them searches for a complementary explanation based on inter-sectoral differences in the probability of exporting due to comparative advantage. We do that by looking at the effect of comparative advantage on the probability of exporting.

The paper uses a novel firm-level dataset with originally constructed measures of comparative advantage from firm data for capital and labor, for 32 countries and 24 sectors. A firm is expected to benefit from comparative advantage if it belongs to capital (respectively labor) intensive sectors in capital (respectively labor) abundant countries.

The remainder of the paper is as follows. Section 2 lays out the model, Section 3 focuses on the key theoretical prediction concerning the probability of exporting, Section 4 discusses the empirical implementation, Section 5 
shows the results and Section 6 concludes.

\section{The Model.}

For convenience of the reader we recall briefly the model structure used in Bernard, Redding and Schott (2007) and then highlight the results of interest for our empirical verification. The model merges a two-by-two HeckscherOhlin structure with monopolistic competition and heterogenous firms. The world economy is composed by two countries, indexed by $c=\{H, F\}$, and produces two differentiated goods, indexed by $i=\{Y, Z\}$. There are two primary factors, skilled and unskilled labour, indexed by $j=\{K, L\}$. Each country is endowed with a fraction $s_{j}^{c}$ of world's endowments, $\bar{K}, \bar{L}$.

\subsection{Preferences and Technology.}

The representative consumer's utility function is assumed to be Cobb-Douglas in the CES aggregates of all varieties of each good produced: $U=\left(C_{Y}\right)^{\gamma_{1}}\left(C_{Z}\right)^{\gamma_{2}}$, with $\gamma_{i} \in(0,1)$, and $\gamma_{Y}+\gamma_{Z}=1$. Each argument $C_{i}$ is a CES consumption index for industry $i$ defined over consumption of each variety $c_{i}(\xi)$ in the set of all varieties of the same industry, $\Xi_{i}$, and with elasticity of substitution between any two varieties equal to $\sigma$. The price index $P_{i}^{c}$ associated with the CES sub-utility is $P_{i}^{c}=\left[\int_{\xi \in \Xi_{i}}\left[p_{i}^{c}(\xi)\right]^{1-\sigma} d \xi\right]^{\frac{1}{1-\sigma}}$ where $p_{i}^{c}(\xi)$ is the price paid 
in $c$ for the variety $\xi$ of good $i$.

Production requires fixed and variable inputs each period and it is assumed that the cost function takes the Cobb-Douglas form

$$
T C_{i}^{c}=\left(F_{i}+\frac{q_{i}}{\phi}\right)\left(w_{L}^{c}\right)^{\alpha_{i}}\left(w_{K}^{c}\right)^{1-\alpha_{i}}, \quad \alpha_{i} \in(0,1), \quad \alpha_{1}+\alpha_{2}=1
$$

where $q_{i}$ is firm's output, $\alpha_{i}$ is cost share of $L$ in industry $i$; the constant $F_{i}>0$ is an index of fixed cost and $w_{L}^{c}$ and $w_{K}^{c}$ are the price of $L$ and $K$, respectively. The productivity parameter $\phi$ is drawn from a probability distribution $g(\phi)$ defined over the interval $(0, \infty)$. Later we shall specify the probability distribution but we need not doing it until section 3 . For clarity of exposition, throughout the paper we assume that $H$ is $K$-abundant and that $Y$ is $K$-intensive, i.e., $s_{K}^{H}>s_{L}^{H}$ and $\alpha_{Y}<\alpha_{Z}$.

Trade cost have a fixed component that requires a fix input of factors in the same proportions as in production. The fix export cost are $F_{i x}\left(w_{L}^{c}\right)^{\alpha_{i}}\left(w_{K}^{c}\right)^{1-\alpha_{i}}$ where $F_{i x}$ is a positive constant. In addition to the fix export cost there is an iceberg-type variable cost by which for a unit of a good shipped only a fraction $\tau_{i} \in(0,1)$ arrives at destination. Clearly, the presence of fix export cost makes that only the most productive firms will find it profitable to export. ${ }^{4}$

\footnotetext{
${ }^{4}$ It may be noted that fix production and fix export cost are assumed to be homogenous across firms reflecting the idea that fix cost are unlikely to vary with firms productivity. This is an innocuous assumption that may be removed without any qualitative change to the results. Fix factors inputs are imputed in the same proportions as variable inputs thus
} 


\subsection{Prices, revenues, and profits.}

Utility maximization and aggregation over individual gives total demand for any variety. Since the demand for a variety is the revenue of the firm producing that variety we shall use the letter $r$ to refer to either of them. Demand for a variety emanates from domestic and (if the firm exports) from foreign residents. Let $p_{i d}^{c}(\phi)$ and $p_{i x}^{c}(\phi)$ represent the price charged by a firm in $c$ with productivity $\phi$ to domestic and foreign residents, respectively. Firm's revenue in the domestic market (demand emanating from domestic residents) is $r_{i d}^{c}(\phi)=\left(p_{i d}^{c}\right)^{1-\sigma}\left(P_{i}^{c}\right)^{\sigma-1} \gamma_{i} R^{c}$ where $R^{c}$ is national income in $c$ equal to aggregate firms revenue. Revenue on the foreign market (demand emanating from foreign residents) for an exporting firm in $H$ is $r_{i x}^{H}(\phi)=\left(p_{i x}^{H}\right)^{1-\sigma}\left(P_{i}^{F}\right)^{\sigma-1} \gamma_{i} R^{F}$ and for an exporting firm in $F$ is $r_{i x}^{F}(\phi)=\left(p_{i x}^{F}\right)^{1-\sigma}\left(P_{i}^{H}\right)^{\sigma-1} \gamma_{i} R^{H}$. Given these demand functions the profitmaximizing price in the domestic market is $p_{i d}^{c}(\phi)=\frac{\sigma}{\sigma-1} \frac{1}{\phi}\left(w_{L}^{c}\right)^{\alpha_{i}}\left(w_{S}^{c}\right)^{1-\alpha_{i}}$ and in the foreign market is $p_{i x}^{c}(\phi)=\frac{1}{\tau_{i}} p_{i d}^{c}(\phi)$. Foreign sales relative to domestic sales for an exporting firm in $H$ are

$$
\frac{r_{i x}^{H}(\phi)}{r_{i d}^{H}(\phi)}=\frac{\tau^{\sigma-1}\left(P_{i}^{F}\right)^{\sigma-1} R^{F}}{\left(P_{i}^{H}\right)^{\sigma-1} R^{H}} .
$$

guaranteeing homothetic technology. This assumption is made for analytic convenience and may be removed at the cost of generating the same kind of complication that arise in the traditional Heckscher-Ohlin model when the assumption of homothetic technology is abandoned. 
An analogous expression applies to an exporting firm in $F$ after switching country superscripts appropriately. Total firm's revenue, $r_{i}^{c}(\phi)$, is equal to $r_{i d}^{c}(\phi)$ if the firm does not exports and is equal to $r_{i d}^{c}(\phi)+r_{i x}^{c}(\phi)$ if the firm exports.

It is useful to note at this point that the revenue of a firm relative to that of any other firm in the same market depends solely on productivity. To see this consider two firms with productivity draws $\phi^{\prime}$ and $\phi^{\prime \prime}$, respectively. Then, computing the ratio of revenues in the same market we obtain

$$
\frac{r_{i d}^{c}\left(\phi^{\prime}\right)}{r_{i d}^{c}\left(\phi^{\prime \prime}\right)}=\left(\frac{\phi^{\prime}}{\phi^{\prime \prime}}\right)^{\sigma-1}=\frac{r_{i x}^{c}\left(\phi^{\prime}\right)}{r_{i x}^{c}\left(\phi^{\prime \prime}\right)}
$$

where, obviously, the second equality applies only to a pair of exporting firms. This relationship will become useful below.

Firm's profit on the domestic market and, for exporting firms only, on the foreign market are, respectively,

$$
\begin{aligned}
& \pi_{i d}^{c}(\phi)=\frac{r_{i d}^{c}(\phi)}{\sigma}-F_{i}\left(w_{L}^{c}\right)^{\alpha_{i}}\left(w_{K}^{c}\right)^{1-\alpha_{i}} \\
& \pi_{i x}^{c}(\phi)=\frac{r_{i x}^{c}(\phi)}{\sigma}-F_{i x}\left(w_{L}^{c}\right)^{\alpha_{i}}\left(w_{K}^{c}\right)^{1-\alpha_{i}}
\end{aligned}
$$

where, for convenience, fixed production cost have been apportioned entirely to domestic profit and fixed exporting cost have been apportioned entirely 
to foreign profit.

\subsection{Equilibrium and Aggregation.}

In addition to utility and profit maximization there are seven equilibrium conditions: (I) successful entry, (II) successful exporting, (III) relationship between foreign and domestic sales, (IV) free entry, (V) stationarity, (VI) goods market equilibrium, (VII) factors market equilibrium.

(I) Successful entry. A firm will produce if $\pi_{i d}^{c}(\phi) \geq 0$ and not produce otherwise. This condition defines the zero-profit productivity cut off, $\phi_{i}^{* c}$, as the least value of $\phi$ such that profit is non negative. By definition, $\phi_{i}^{* c}$ satisfies $\pi_{i d}^{c}\left(\phi_{i}^{* c}\right)=0$. Using (4) we can write the cut off conditions as:

$$
r_{i d}^{c}\left(\phi_{i}^{* c}\right)=\sigma F_{i}\left(w_{L}^{c}\right)^{\alpha_{i}}\left(w_{K}^{c}\right)^{1-\alpha_{i}}
$$

(II) Successful exporting. A firm will export if $\pi_{i x}^{c}(\phi) \geq 0$ and not export otherwise. This condition defines the zero-exporting-profit productivity cut off, $\phi_{i x}^{* c}$, as the least value of $\phi$ such that foreign profit is non negative. By definition, $\phi_{i x}^{* c}$ satisfies $\pi_{i x}\left(\phi_{i x}^{* c}\right)=0$. 
Using (5) we can write the cut off conditions as:

$$
r_{i x}^{c}\left(\phi_{i x}^{* c}\right)=\sigma F_{i x}\left(w_{L}^{c}\right)^{\alpha_{i}}\left(w_{K}^{c}\right)^{1-\alpha_{i}}
$$

(III) Relationship between foreign and domestic sales. Applying equation (3) to any firm relative to the cut off firm and using (6)-(7) allows writing the revenue of any firm as follows:

$$
\begin{aligned}
& r_{i d}^{c}(\phi)=\left(\frac{\phi}{\phi_{i}^{* c}}\right)^{\sigma-1} \sigma F_{i}\left(w_{L}^{c}\right)^{\alpha_{i}}\left(w_{K}^{c}\right)^{1-\alpha_{i}} \\
& r_{i x}^{c}(\phi)=\left(\frac{\phi}{\phi_{i x}^{* c}}\right)^{\sigma-1} \sigma F_{i x}\left(w_{L}^{c}\right)^{\alpha_{i}}\left(w_{K}^{c}\right)^{1-\alpha_{i}}
\end{aligned}
$$

Combining these two expressions with expression (2) gives an equilibrium relationship which allows relating the cut off values as follows:

$$
\phi_{i x}^{* c}=\Lambda_{i}^{c} \phi_{i}^{* c}
$$

where

$$
\begin{aligned}
\Lambda_{i}^{H} & \equiv \frac{1}{\tau_{i}}\left(\frac{P_{i}^{H}}{P_{i}^{F}}\right)\left(\frac{R^{H}}{R^{F}} \frac{F_{i x}}{F_{i}}\right)^{\frac{1}{\sigma-1}} \\
\Lambda_{i}^{F} & \equiv \frac{1}{\tau_{i}}\left(\frac{P_{i}^{F}}{P_{i}^{H}}\right)\left(\frac{R^{F}}{R^{H}} \frac{F_{i x}}{F_{i}}\right)^{\frac{1}{\sigma-1}}
\end{aligned}
$$


Aggregation. It is useful at this point to define the average productivity for all firms and exporting firms, respectively. The former depends on the zero-profit productivity cut off and the latter depends on the zero-exportingprofit productivity cut off. They are, respectively:

$$
\widetilde{\phi}_{i}^{* c}=\left[\frac{1}{1-G\left(\phi_{i}^{* c}\right)} \int_{\phi_{i}^{* c}}^{\infty} \phi^{\sigma-1} g(\phi) d \phi\right]^{\frac{1}{\sigma-1}} \text { and } \widetilde{\phi}_{i x}^{* c}=\left[\frac{1}{1-G\left(\phi_{i x}^{* c}\right)} \int_{\phi_{i x}^{* c}}^{\infty} \phi^{\sigma-1} g(\phi) d \phi\right]^{\frac{1}{\sigma-1}} \text {. }
$$

We can now write the average (or expected) value of revenues and profits in terms of average productivity. Computing average domestic sales, $\bar{r}_{i d}^{c}$ and average foreign sales, $\bar{r}_{i x}^{c}$, from expressions (8)-(9) we obtain $\bar{r}_{i d}^{c}\left(\phi_{i}^{* c}\right)=$ $\frac{1}{1-G\left(\phi_{i}^{* c}\right)} \int_{\phi_{i}^{* c}}^{\infty} r_{i d}^{c}(\phi) g(\phi) d \phi=r\left(\widetilde{\phi}_{i}^{* c}\right)$ and, analogously, $\bar{r}_{i x}^{c}\left(\phi_{i x}^{* c}\right)=r\left(\widetilde{\phi}_{i x}^{* c}\right)$ which means that the average domestic or foreign revenue is equal to the revenue of the firm with $\phi$ equal to $\widetilde{\phi}_{i}^{* c}$ or $\widetilde{\phi}_{i x}^{* c}$, respectively. Likewise, computing average (or expected) profit we obtain $\bar{\pi}_{i d}^{c}\left(\phi_{i}^{* c}\right)=\pi_{i d}^{c}\left(\widetilde{\phi}_{i}^{* c}\right)$ and $\bar{\pi}_{i x}^{c}\left(\phi_{i x}^{* c}\right)=\pi_{i x}^{c}\left(\widetilde{\phi}_{i x}^{* c}\right)$. Finally, average prices are $\bar{p}_{i d}^{c}\left(\phi_{i}^{* c}\right)=p_{i d}^{c}\left(\widetilde{\phi}_{i}^{* c}\right)$ and $\bar{p}_{i x}^{c}\left(\phi_{i}^{* c}\right)=p_{i x}^{c}\left(\widetilde{\phi}_{i}^{* c}\right)$.

(IV) Free entry. Potential entrants arbitrage between the cost and the expected benefit of entry. Entry cost is paid in terms of inputs of both factors and is equal to $F_{e i}\left(w_{L}^{c}\right)^{\alpha_{i}}\left(w_{K}^{c}\right)^{1-\alpha_{i}}$. After entry, firms face a constant and exogenous probability of death $\delta$ due to exogenous and unforeseeable events. The value of the firm is either equal to 0 (if the firm draw is $\phi<\phi_{i}^{* c}$ ) or equal $\pi_{i}^{c} / \delta$ (if the firm draw is $\phi>\phi_{i}^{* c}$ ) which is the total profit discounted 
by the probability of death. Total profit, $\pi_{i}^{c}$, is equal to $\pi_{i d}^{c}$ if the firm does not export $\left(\phi_{i x}^{* c}>\phi>\phi_{i}^{* c}\right)$ and is equal to $\pi_{i d}^{c}+\pi_{i x}^{c}$ if the firm exports $\left(\phi>\phi_{i x}^{* c}\right)$. The value of a firm therefore is known only after having drawn $\phi$ but its expected value is known ex-ante and depends on the zero-profit and zero-exporting-profit productivity cut off. Let $\chi_{i}^{c}$ represent the the ex-ante probability of exporting conditional to successful entry,

$$
\chi_{i}^{c}=\frac{1-G\left(\phi_{i x}^{* c}\right)}{1-G\left(\phi_{i}^{* c}\right)}
$$

where the numerator is the probability of exporting and the denominator is the probability of successful entry. Then the value of entry, $V_{i}^{c}$, is given by the stream of expected profits conditional to successful entry discounted by the probability of death: i.e., $V_{i}^{c}=\frac{1}{\delta}\left[1-G\left(\phi_{i}^{* c}\right)\right]\left[\bar{\pi}_{i d}^{c}\left(\phi_{i}^{* c}\right)+\chi_{i}^{c} \bar{\pi}_{i x}\left(\phi_{i x}^{* c}\right)\right]$

The presence of an infinity of potential entrants erodes any possible divergence between the value of entry and the entry cost. Therefore, the free entry condition requires:

$$
V_{i}^{c}=F_{e i}\left(w_{L}^{c}\right)^{\alpha_{i}}\left(w_{K}^{c}\right)^{1-\alpha_{i}}
$$

(V) Stationarity. In a stationary equilibrium the mass of potential entrants, $M_{e i}^{c}$, must be such that the mass of successful entrants, $\left[1-G\left(\phi_{i}^{*}\right)\right] M_{e i}^{c}$, 
equal the mass of incumbent firms who die, $\delta M_{i}^{c}$; that is: $\left[1-G\left(\phi_{i}^{* c}\right)\right] M_{e i}^{c}=$ $\delta M_{i}^{c}$

(VI) Goods market equilibrium. Equilibrium in goods markets requires that the average value of output in any industry and country equal the average expenditure on that country's industry output. Using equations (3) and (6)-(7) and aggregating we obtain the value of average output: $\bar{r}_{i d}^{c}=$ $\left(\frac{\widetilde{\phi}_{i}^{* c}}{\phi_{i}^{* c}}\right)^{\sigma-1} \sigma F_{i}\left(w_{L}^{c}\right)^{\alpha_{i}}\left(w_{K}^{c}\right)^{1-\alpha_{i}}$, and $\bar{r}_{i x}^{c}=\left(\frac{\widetilde{\phi}_{i x}^{* c}}{\phi_{i x}^{* c}}\right)^{\sigma-1} \sigma F_{x i}\left(w_{L}^{c}\right)^{\alpha_{i}}\left(w_{K}^{c}\right)^{1-\alpha_{i}}$. Computing the value of average demand from demand functions and equating it to average value of output we obtain the equilibrium in goods market:

$$
\begin{aligned}
& \bar{r}_{i}^{H}=\left(\frac{\bar{p}_{i d}^{H}}{P^{H}}\right)^{1-\sigma} \gamma_{i} R^{H}+\chi_{i}^{H} \tau^{\sigma-1}\left(\frac{\bar{p}_{i d}^{H}}{P^{F}}\right)^{1-\sigma} \gamma_{i} R^{F} \\
& \bar{r}_{i}^{F}=\left(\frac{\bar{p}_{i d}^{F}}{P^{F}}\right)^{1-\sigma} \gamma_{i} R^{F}+\chi_{i}^{F} \tau^{\sigma-1}\left(\frac{\bar{p}_{i d}^{F}}{P^{H}}\right)^{1-\sigma} \gamma_{i} R^{H} .
\end{aligned}
$$

(VII) Factors market equilibrium. Equilibrium in factors market requires factors demand for production and entry to equal the constant supply of every factor in every country:

$$
\begin{aligned}
\sum_{i}\left(L_{i p}^{c}+L_{i e}^{c}\right) & =s_{L}^{c} \bar{L} \\
\sum_{i}\left(S_{i p}^{c}+S_{i e}^{c}\right) & =s_{k}^{c} \bar{K}
\end{aligned}
$$


where the second subscripts $p$ and $e$ borne by factors demand refer to production and entry, respectively.

Counting equations and endogenous. After appropriate substitutions of the related expressions the system counts fifteen equations which together with one normalization determine sixteen endogenous variables. The equations are the four relationships between foreign and domestic sales in (10), the four free entry conditions (14), the four factors market clearing conditions (17)-(18), and any three out of the four goods market equilibrium conditions (15)-(16). The endogenous are the four factor prices $\left\{w_{S}^{c}, w_{L}^{c}\right\}$, the four zero-profit productivity cut off $\left\{\phi_{i}^{* c}\right\}$, the four zero-foreign-profit productivity cut off $\left\{\phi_{i x}^{* c}\right\}$, and the four masses $\left\{M_{i}^{c}\right\}$.

\section{Theoretical results.}

To show the relationship between the comparative advantage and the probability of exporting we begin by noting that in autarky and in costly trade the relative price index for the $K$-intensive good is lower in the $K$-abundant country:

$$
\frac{P_{Y}^{H}}{P_{Z}^{H}}<\frac{P_{Y}^{F}}{P_{Z}^{F}} \text { or, equivalently, } \frac{P_{Y}^{H}}{P_{Y}^{F}}<\frac{P_{Z}^{H}}{P_{Z}^{F}}
$$


This inequality rests on the positive relationship between the relative price and relative scarcity of a factor whenever trade is not completely free. From this inequality and using equation (11)-(12) we see that, absent any crossindustry difference in fixed costs and trade costs, we have $\Lambda_{Y}^{H}<\Lambda_{Z}^{H}$ and $\Lambda_{Z}^{F}<\Lambda_{Y}^{F}$. From these inequalities, using (10), we obtain that the zero-profit and zero-exporting-profit productivity cut off are closer to each other in the industry of comparative advantage: ${ }^{5}$

$$
\frac{\phi_{Y x}^{* H}}{\phi_{Y}^{* H}}<\frac{\phi_{Z x}^{* H}}{\phi_{Z}^{* H}} \text { and } \frac{\phi_{Z x}^{* F}}{\phi_{Z}^{* F}}<\frac{\phi_{Y x}^{* F}}{\phi_{Y}^{* F}}
$$

We now specify the probability distribution by assuming that it is Pareto with cumulative distribution $G(x)=1-\left(\frac{\phi_{m}}{\phi}\right)^{k}$, with shape parameter $k$, with $\phi>\phi_{m}>0$ where $\phi_{m}$ is an arbitrary minimum level of productivity whose value plays no role in the results that follow. ${ }^{6}$ Using the Pareto distribution in (13), the ex ante probability of exporting is $\chi_{i}^{c}=\left(\frac{\varphi_{i}^{* C}}{\varphi_{i x}^{* C}}\right)^{k}$, from which,

\footnotetext{
${ }^{5}$ The inequalities concerning $\Lambda_{i}^{c}$ as well as inequalities (20) are proven in Bernard, Redding and Schott (2007) where inequalities (20) appear in Proposition 4, sub b), page 45 .

${ }^{6}$ The Pareto distribution is often used in the theoretical literature; see, for instance, Bernard, Eaton, Jensen, and Kortum (2003); Melitz and Ottaviano (2008); Eaton et al. (2008), and Chaney (2010). The Pareto distribution also seems to find empirical support. A very early evidence on this matter is Simon and Bonini (1958) who first noted that the Pareto distribution replicates well the distribution of firm size. More recent evidence include Axtell (2001), Luttmer (2007), Helpman, Melitz and Yeaple (2004), Del Gatto, Mion and Ottaviano (2006), while Combes, Duranton, Gobillon, Puga and Roux (2009) find no supporting evidence.
} 
using using (20) into (13), we obtain the following inequality:

$$
\chi_{Y}^{H}>\chi_{Z}^{H} \text {, and } \chi_{Z}^{F}>\chi_{Y}^{F} .
$$

which means that:

Ceteris paribus, the ex-ante probability of exporting is larger in the industry of comparative advantage $e^{7}$

As discussed above, a firm exports if foreign profits are non-negative and does not export otherwise. But foreign profits (like foreign revenues, total revenues and total profits) are increasing in productivity. Therefore:

The probability of exporting is increasing with firm productivity.

In the model, the effect of networks on the probability of export may be thought as affecting the fix exporting cost, $F_{x}$, whereby firms with better links to international exports have lower $F_{x}$. Then, by virtue of equation (7) we have that:

\footnotetext{
${ }^{7}$ The ceteris paribus condition refers to asymmetries in fix cost or variable trade cost. Inequalities (21) may not hold when there are cross-industry differences in fixed costs and trade costs. However, the degrees of freedom given by the four parameters involved in cross-industry differences (trade costs, fixed entry, fixed production, and fixed exporting costs) assures that inequalities (21) may hold even in the presence of large differences in any cross-industry pair of these parameters.
} 
A firm with better networking connections would have a higher probability of exporting.

These three results related to the effect of productivity, comparative advantage, and networking on the probability of exporting can be summarized in the following relationships to be tested empirically:

Prob. of Exp. = f(comparative advantage, productivity, networking connection).

The relationship between productivity, network connections, and the probability of exporting is straightforward. Let us offer additional intuition on the economic mechanism that links comparative advantage to the probability of exporting. In costly trade the Heckscher-Ohlin specialization mechanism assures that the mass of firms in the industry of comparative advantage relative to the industry of comparative disadvantage increases. This, causes market crowding in the industry of comparative advantage in both countries while the opposite occurs in the industry of comparative disadvantage. As a consequence, in the comparative advantage industry in each country foreign sales (and foreign profit) relative to domestic sale (and profit) are higher than in the comparative disadvantage industry; this is indeed reflected in equa- 
tions (11)-(12) after using (19). This makes that probability of exporting is higher in the industry of comparative advantage.

\section{Empirical Implementation.}

In this section we describe the data and the way variables are constructed.

\subsection{Data description.}

We use the Enterprise Survey firm-level dataset which is based on a survey organized by the World Bank.

We derive an export dummy (=1 if the firm exports, and 0 otherwise) from the information on whether the firm exports. Tables 1 and 2 present the percentage of firms that export, by country and by industry respectively. Note that about 30 percent of firms in our sample are exporters but the percentage is only 8 percent for smaller firms, is about 25 percent for medium size firms and is 51 percent for larger firms.

In order to construct original measures of firms' capital labor ratios, we use capital in local currency from the sum of the net book value of "Machinery and Equipment (including Transport)" and the one of "Land, Building and Leasehold Improvements", while employment is measured from the "Average 
Number of Permanent Workers". We convert sales and capital in dollar terms (via bilateral exchange rates from International Financial Statistics from IMF) for comparability; as we use also country fixed effects in the regressions, such normalizations have no bearing on the results. Figures 1 and 2 present the histograms of the newly constructed capital labor ratios by country and by industry.

As indicators of firms' size we employ both sales in local currency from "Total Sales" and employment. We carefully check the data for extreme values (dropping few firms whose employment or sales would be reported as larger than national aggregate indicators available in standard macroeconomic databases such as World Bank or IFS), consistency checks (dropping firms where reported categories of employment would not add up to total reported firm employment, or reported categories of capital would not add up to total reported firm capital), and for outliers (observations deviating from the country-industry mean by more than three standard deviations, in $\log$ terms). After data cleanup, our data set encompasses about 8,000 firms in 24 industries and 32 countries. $^{8}$

\footnotetext{
${ }^{8}$ The industries in our sample are: Textiles; Leather; Garments; Agroindustry; Food; Beverages; Metals and machinery; Electronics; Chemicals and pharmaceuticals; Construction; Wood and furniture; Non-metallic and plastic materials; Paper; Sport goods; IT services; Other manufacturing; Accounting and finance; Advertising and marketing; Other services; Retail and wholesale trade; Transport; Mining and quarrying; Auto and auto
} 
As indicators of networks, we use several measures related to firms' connections via foreign, domestic, communication, state, or unionization networks. See the Appendix table, for descriptive statistics on all variables.

\subsection{Empirical specification.}

The empirical methodology adopts the following probit regression

$$
\Psi_{c i j}=\varsigma_{i}+\varsigma_{c}+\xi X_{c i j}+\epsilon_{c i j}
$$

of the export dummy $\Psi_{c i j}$ for firm $j$ in industry $i$ of country c. The dependent variable is regressed on various determinants $X_{c i j}$ : sales, employment, comparative advantage, and variables related to firms' connections to networks. Regressions include country and industry fixed effects and are estimated with robust or clustered standard errors.

Our measures of productivity and comparative advantage are generated as follows. Coherently with the theoretical model we use sales and employment as a proxy for productivity in our regressions. ${ }^{9}$ We also use sales,

components; Other transport equipment. The countries in the sample (with the respective year of survey) are: Algeria 2002; Bangladesh 2002; Chile 2004; China 2003; Ecuador 2003; Egypt 2004; El Salvador 2003; Ethiopia 2002; Guatemala 2003; Honduras 2003; India 2000; Kosovo 2003; Kyrgyzstan 2003; Lithuania 2004; Madagascar 2005; Malawi 2005; Mauritius 2005; Morocco 2004; Nicaragua 2003; Pakistan 2002; Philippines 2003; Poland 2003; Serbia 2003; South Africa 2003; Sri Lanka 2004; Tajikistan 2003; Tanzania 2003; Thailand 2004; Turkey 2005; Uzbekistan 2003; Vietnam 2005; Zambia 2002.

${ }^{9}$ Sales are often used to proxy productivity, see, e.g., Helpman et al. (2004) and Eaton et al. (2008). 
employment, and the capital/labor ratio jointly in the regression, which is somewhat equivalent to entering another proxy for total factor productivity at the firm level (i.e., the value that would result from regressing sales on employment and capital controlling for country and industry dummies).

In the model, the comparative advantage of a country is determined as in the traditional Heckscher-Ohlin setup. Coherently with the model, we define comparative advantage on the basis of the capital and labor indicators. Capital (labor) intensive industries are defined as those where the capital labor ratio of the median firm in the industry is larger (lower) than the capital labor ratio for the median firm in the country. Capital (labor) abundant countries are defined as those where capital labor ratio of the median firm in the country is larger (lower) than the capital labor ratio for the median firm in the data set. ${ }^{10}$ The comparative advantage dummy variable takes the value of 1 if a firm either belongs to the capital intensive industry of a capital abundant or to a labor intensive industry of a labor abundant country and takes the value of 0 otherwise.

\footnotetext{
${ }^{10}$ This is coherent with the theoretical definition. In a two-country world the inequality $s_{K}^{H}>s_{L}^{H}$ implies that country $H$ is absolutely $K$-abundant; i.e., $K^{H} / L^{H}>K^{F} / L^{F}$. In a multi-country world the inequality $s_{K}^{c}>s_{L}^{c}$ correspond to Leamer (1980) definition of relative abundance which implies that $K^{c} / L^{c}>\bar{K} / \bar{L}$. The capital labor ratio of the median firm corresponds to $K^{c} / L^{c}$ and the capital labor ratio of the dataset corresponds to $\bar{K} / \bar{L}$.
} 


\section{Empirical results.}

We first explore, in Table 3, the effect of the most innovative measure of our paper (the proxy for comparative advantage) on the probability of exporting, controlling for proxies of productivity as well as country and industry fixed effects. In order to offer a standard benchmark, the first two columns of Table 3 show univariate probit regressions of the export dummy on productivity (proxied by sales or employment). ${ }^{11}$ Both proxies have a positive and significant effect which confirms a result already well established in the literature.

The third column of Table 3 shows the impact of the comparative advantage dummy. The impact is positive and significant as predicted by the model. Column four and five show that both the effects of productivity and that of comparative advantage remain positive and significant when entered jointly. Column six shows that the same qualitative result arises when both proxies for productivity are present in addition to the comparative advantage. The difference with columns 4 and 5 is that coefficients for both proxies of productivity decline when both variables are present, which is not surprising as they are positively correlated with each other. Column 7 enters the

\footnotetext{
${ }^{11}$ The coefficients in the tables with probit regressions represent marginal effect, i.e. the change in the probability for an infinitesimal change in each independent, continuous variable.
} 
capital labor ratio in the regression and shows that our results are robust to such an inclusion. There are two reasons for being interested in entering the capital labor ratio in the regression. First, it is the variable underlying the construction of our measure of comparative advantage, so adding it to the regression addresses possible suspicion that this measure may simply be capturing the effect of the capital labor ratio. The result confirm that this is not the case, which is not surprising, given that the measure of comparative advantage is a highly nonlinear transformation of the ratio. Second, using capital labor ratio at the same time as sales and labor as regressors is equivalent to controlling for another proxy of productivity, i.e., the proxy that would result from regressing sales on capital and labor controlling for country and industry fixed effects: notably, the coefficient for comparative advantage is unaffected either in size or significance.

As our indicator of comparative advantage would be the same for all firms in a country-industry, we cannot include country-industry dummies, but we include country and industry dummies. Moreover, we check whether results change when clustering the errors at the country-industry level. The results presented in Table 4 show that the estimated value and significance of all coefficients remains are remarkably stable. ${ }^{12}$

\footnotetext{
${ }^{12}$ Results are also robust to dropping country and fixed effects.
} 
Tables 5 and 6 show the importance of factors related to various forms of firms' connections to networks as well as the robustness of the results related to comparative advantage. Firms' foreign connections (Foreign financing, Foreign joint venture, and Foreign participation) are all positively related to the probability of exporting. Firms are also more likely to export if they have more advanced communication technologies (Firm uses E-mail and Firm has a web site), or stronger domestic connections, indicated for example by being part of chamber of commerce (Firm part of Chamber of Commerce) or by the time inputted into administrative matters (Time spent with gov't regulations). Conversely, firms under public control (State participation) or where the labor force is highly unionized (Unionization) tend to export less. Lastly, younger firms tend to be associated with a higher export probability. ${ }^{13}$ This is at odd with the literature on advanced economies (see for example Barba Navaretti et al., 2010), where more established firms are more likely to export, and may reflect the more vibrant nature of the developing countries in our sample. When all variables enter the regression simultaneously (last column), they remain highly significant, with the exception of unionization, even if the sample size drops a lot.

\footnotetext{
${ }^{13}$ Given the presence of fixed effects, the variable related to the age of the firm is automatically equivalent to years since creation, despite the (slight) difference in years of the survey across countries
} 
The results are highly robust. In Table 6 we see that the clustering of error terms leaves results unchanged. In particular, the first three rows of Tables 5 and 6 show that size and comparative advantage remain significant as determinant of the export probability when additional variables are included in the regressions.

\section{Conclusions.}

What determines the export performance of firms? Recent developments in the vein of Melitz (2003) and implications that may be derived from Bernard Redding Schott (2007) point at productivity and comparative advantage as two key determinants. A separate strand of literature over the past decade has highlighted the importance of networking connections (e.g., Rauch, 2001, and Casella and Rauch, 2002). The empirical literature has extensively documented the importance of productivity for the export performance of firms. Evidence of the role of comparative advantage has mainly been indirect (via net factor content of trade, or the predictions of the home market effect and of productions patterns) and its effect on the probability of exporting has not been investigated. Evidence on the effect of networks is very limited. This paper makes use of a cross-country and multi-sector firm level data to 
jointly confirm these theories.

In particular, this paper constructs indicators of comparative advantage on the basis of firm level capital labor ratios: capital intensive firms in capital abundant countries or labor intensive firms in labor abundant countries enjoy a comparative advantage compared to their peers. This variable presents a strong positive association with the export performance of firms, even when controlling for country and sector fixed effects, as well for the role of firm' size and of other variables related to firms connections.

Our results also confirm the importance of networks. Firms are more likely to export if they benefit from foreign networks (foreign financing, joint venture, foreign ownership), communication networks (E-mail, web site), and domestic networks (chamber of commerce, regulation) while their export performance suffers from the presence of state or labor networks. Younger firms are more likely to export.

The results presented above establish associations between export performance and the regressors of interest: productivity, comparative advantage and network variables. As such, they are not immune from endogeneity concerns. For example, the results do not allow to distinguish whether a firm that has better communication networks finds it easier to export and decides to export, or whether a firm that decides to export realizes it needs better communication networks. Either way, the results indicate what firms do 
when they exports. However, theory suggests that these associations should reflect causality or necessary conditions.

Looking forward, an ambitious research agenda would enlist merging this dataset with other firm level datasets encompassing more advanced countries and similar sectors, so as to obtain a broader representation of countries, which would favor a better assessment of the comparative advantage.

\section{References}

[1] Aitken Brian, Gordon H. Hanson, Ann E. Harrison (1997) "Spillovers, foreign investment, and export behavior" Journal of international economics 43: 103-132.

[2] Axtell, Robert L. (2001) "Zipf Distribution of U. S. Firm Sizes." Science, 293(5536): 1818-20.

[3] Barba Navaretti, G., Matteo Bugamelli, Fabiano Schivardi, Carlo Altomonte, Daniel Horgos, and Daniela Maggioni (2010) "The global operations of European firms", mimeo, Efige and Centro Studi Luca D'Agliano.

[4] Bernard, Andrew B., Eaton, Jonathan, Jensen, J. Bradford, and Kortum, Samuel (2003) "Plants and Productivity in International 
Trade." American Economic Review, 93: 1268-1290.

[5] Bernard, Andrew B. and J. Bradford Jensen (1999) "Exceptional Exporter Performance: Cause, Effect, or Both." Journal of International Economics 47: 1-25.

[6] Bernard B. Andrew and J. Bradford Jensen (2004) "Why Some Firms Export." Review of Economics and Statistics 86: 561-569.

[7] Bernard B. Andrew, J. Bradford Jensen, Stephen Redding, and Peter K. Schott (2007) "Firms in International Trade." Journal of Economic Perspectives 21(3): 105-130.

[8] Bernard B. Andrew, Stephen J. Redding, Peter K. Schott (2007) "Comparative Advantage and Heterogenous Firms" Review of Economic Studies 74: 31-66.

[9] Casella, A. and Rauch, J. (2002) "Anonymous market and group ties in international trade", Journal of International Economics, vol. 58(1), pp. $19-47$.

[10] Chaney, Thomas (2008) "Distorted Gravity: Heterogeneous Firms, Market Structure, and the Geography of International Trade," American Economic Review, 98: 1707-1721. 
[11] Combes, Pierre-Philippe, Lafourcade Miren, and Mayer Thierry (2005) "The trade creating effects of business and social networks: evidence from France" Journal of International Economics 66:1-29.

[12] Combes Pierre-Philippe, Duranton Gilles, Gobillon Laurent, Puga Diego, and Roux Sébastien (2009) "The Productivity Advantage of Large Markets: Distinguishing Agglomeration from Firm Selection" CEPR Discussion Paper 7191.

[13] Crozet M. and P. Koenig (2010) "Structural gravity equation with extensive and intensive margins". Canadian Journal of Economics 43(1):

[14] Davis Donald and David Weinstein (2001) "An Account of Global Factor Trade" American Economic Review 91(5):1423-1453

[15] Davis Donald and David Weinstein (2003) "Market Access, Economic Geography and Comparative Advantage: an Empirical Test". Journal of International Economics 59, 1-23.

[16] Del Gatto Massimo, Mion Giordano, and Ottaviano, Gianmarco I. P. (2006) "Trade Integration, Firm Selection and the Costs of Non-Europe" (Mimeo, University of Bologna).

[17] Eaton, Jonathan, Samuel Kortum, and Francis Kramarz (2008) "An Anatomy of International Trade: Evidence from French Firms." mimeo. 
[18] Hanson Gordon H. and Chong Xiang (2004) "The Home Market Effect and Bilateral Trade Patterns", American Economic Review, 94: 11081129.

[19] Hanson Gordon H. and Chong Xiang (2008) "Testing the Melitz Model of Trade: an application to U.S. Motion Picture exports", Mimeo.

[20] Hausmann, Ricardo, Jason Hwang, and Dani Rodrik. (2007) "What You Export Matters." Journal of Economic Growth 12(1): 1-25.

[21] Head, Keith and John Ries (2001) "Increasing Returns Versus National Product Differentiation as an Explanation for the Pattern of US-Canada Trade". American Economic Review, 91: 858-876.

[22] Helpman, Elhanan, Melitz J. Marc and Rubinstein Yona (2008) "Estimating Trade Flows: Trading Partners and Trading Volume", Quarterly Journal of Economics 123 (2): 441-487.

[23] Helpman Elhanan, Marc J. Melitz, Stephen R. Yeaple (2004) "Export Versus FDI with Heterogeneous Firms" American Economic Review 94(1):300-316.

[24] Hidalgo C. A., B. Klinger, A.-L. Barabási, and R. Hausmann (2007) "The Product Space Conditions the Development of Nations" Science 317(27): 482-487. 
[25] Luttmer, Erzo G. J. (2007) "Selection, Growth, and the Size Distribution of Firms." Quarterly Journal of Economics 122(3): 1103-44.

[26] Melitz J. Marc (2003) "The impact of trade on intra-industry reallocations and aggregate industry productivity". Econometrica 71(6):16951725.

[27] Melitz J. Marc and Gianmarco I. P. Ottaviano (2008) "Market Size, Trade, and Productivity", Review of Economic Studies 75: 295-316.

[28] Rauch, James (2001) "Business and social networks in international trade" Journal of Economic Literature 39,1177- 1203.

[29] Rauch, James and Casella Alessandra (2003) "Overcoming Informational Barrieres to International resource Allocation: Prices and Ties" The Economic Journal 113: 21-42.

[30] Rauch, J., Trindade, V. (2002) "Ethnic Chinese networks in international trade" Review of Economics and Statistics 84 (1), 116-130.

[31] Roberts M. and J. Tybout (1997) "The Decision to Export in Colombia: An Empirical Model of Entry with Sunk Costs," , American Economic Review 87(4): 545-563.

[32] Rodrik Dani (2000) "How Far Will International Economic Integration Go?" Journal of Economic Perspectives 14(1):177-186. 
[33] Romalis John (2004) "Factor Proportions and the Structure of Commodity Trade", American Economic Review 91(1): 67-97.

[34] Wagner Joachim (2007) "Exports and Productivity: A Survey of the Evidence from Firm-level Data", The World Economy 30(1): 60-82.

[35] Wagner, D., Head, K., Ries, J. (2002) Immigration and the trade of provinces. Scottish Journal of Political Economy 49 (5), 507-525. 
Table 1

\begin{tabular}{lcccc}
\multicolumn{5}{c}{ Table 1} \\
\multicolumn{1}{c}{ PERCENTAGE OF FIRMS THAT EXPORTS BY COUNTRY } \\
\hline \hline SIZE & 1 & 2 & 3 & TOTAL \\
number employees $\rightarrow$ & $1-24$ & $25-99$ & $100+$ & ALL \\
\hline Algeria2002 & $0 \%$ & $0 \%$ & $4 \%$ & $1 \%$ \\
Bangladesh2002 & $7 \%$ & $23 \%$ & $36 \%$ & $30 \%$ \\
Chile2004 & $10 \%$ & $26 \%$ & $53 \%$ & $30 \%$ \\
China2003 & $4 \%$ & $0 \%$ & $6 \%$ & $4 \%$ \\
Ecuador2003 & $10 \%$ & $22 \%$ & $40 \%$ & $22 \%$ \\
Egypt2004 & $4 \%$ & $20 \%$ & $41 \%$ & $17 \%$ \\
ElSalvador2003 & $5 \%$ & $43 \%$ & $70 \%$ & $35 \%$ \\
Ethiopia2002 & $0 \%$ & $19 \%$ & $8 \%$ & $8 \%$ \\
Guatemala2003 & $11 \%$ & $35 \%$ & $70 \%$ & $31 \%$ \\
Honduras2003 & $6 \%$ & $24 \%$ & $69 \%$ & $19 \%$ \\
India2000 & $47 \%$ & $58 \%$ & $67 \%$ & $60 \%$ \\
Kosovo2003 & $0 \%$ & $17 \%$ & $0 \%$ & $4 \%$ \\
Kyrgyzstan2003 & $7 \%$ & $17 \%$ & $25 \%$ & $15 \%$ \\
Lithuania2004 & $11 \%$ & $42 \%$ & $68 \%$ & $47 \%$ \\
Madagascar2005 & $0 \%$ & $0 \%$ & $75 \%$ & $69 \%$ \\
Malawi2005 & $0 \%$ & $35 \%$ & $44 \%$ & $36 \%$ \\
Mauritius2005 & $0 \%$ & $33 \%$ & $67 \%$ & $40 \%$ \\
Morocco2004 & $21 \%$ & $39 \%$ & $71 \%$ & $50 \%$ \\
Nicaragua2003 & $4 \%$ & $27 \%$ & $46 \%$ & $12 \%$ \\
Pakistan2002 & $8 \%$ & $10 \%$ & $25 \%$ & $10 \%$ \\
Philippines2003 & $6 \%$ & $17 \%$ & $60 \%$ & $35 \%$ \\
Poland2003 & $6 \%$ & $17 \%$ & $45 \%$ & $20 \%$ \\
Serbia2003 & $17 \%$ & $14 \%$ & $20 \%$ & $17 \%$ \\
SouthAfrica2003 & $29 \%$ & $38 \%$ & $54 \%$ & $46 \%$ \\
SriLanka2004 & $10 \%$ & $23 \%$ & $52 \%$ & $38 \%$ \\
Tajikistan2003 & $0 \%$ & $0 \%$ & $0 \%$ & $0 \%$ \\
Tanzania2003 & $26 \%$ & $31 \%$ & $46 \%$ & $33 \%$ \\
Thailand2004 & $19 \%$ & $40 \%$ & $70 \%$ & $61 \%$ \\
Turkey-b2005 & $16 \%$ & $39 \%$ & $65 \%$ & $47 \%$ \\
Uzbekistan2003 & $6 \%$ & $0 \%$ & $0 \%$ & $2 \%$ \\
Vietnam2005 & $7 \%$ & $20 \%$ & $50 \%$ & $35 \%$ \\
Zambia2002 & $21 \%$ & $18 \%$ & $51 \%$ & $31 \%$ \\
\hline ALL countries & $8 \%$ & $25 \%$ & $51 \%$ & $31 \%$ \\
& & & & \\
\hline
\end{tabular}


Table 2

PERCENTAGE OF FIRMS THAT EXPORTS BY INDUSTRY

\begin{tabular}{lcccc}
\hline \hline SIZE & 1 & 2 & 3 & TOTAL \\
number employees $\rightarrow$ & $1-24$ & $25-99$ & $100+$ & ALL \\
\hline Textiles & $7 \%$ & $22 \%$ & $46 \%$ & $30 \%$ \\
Leather & $10 \%$ & $57 \%$ & $75 \%$ & $46 \%$ \\
Garments & $11 \%$ & $39 \%$ & $80 \%$ & $55 \%$ \\
Agroindustry & $23 \%$ & $27 \%$ & $56 \%$ & $38 \%$ \\
Food & $7 \%$ & $24 \%$ & $43 \%$ & $26 \%$ \\
Beverages & $6 \%$ & $14 \%$ & $11 \%$ & $10 \%$ \\
Metals and machinery & $7 \%$ & $26 \%$ & $47 \%$ & $28 \%$ \\
Electronics & $15 \%$ & $16 \%$ & $62 \%$ & $43 \%$ \\
Chemicals and pharmaceutics & $10 \%$ & $20 \%$ & $33 \%$ & $22 \%$ \\
Construction & $7 \%$ & $7 \%$ & $10 \%$ & $8 \%$ \\
Wood and furniture & $4 \%$ & $26 \%$ & $62 \%$ & $26 \%$ \\
Non-metallic and plastic materials & $9 \%$ & $21 \%$ & $43 \%$ & $24 \%$ \\
Paper & $5 \%$ & $10 \%$ & $31 \%$ & $18 \%$ \\
Sport goods & $45 \%$ & $100 \%$ & $100 \%$ & $63 \%$ \\
IT services & $8 \%$ & $11 \%$ & $7 \%$ & $9 \%$ \\
Other manufacturing & $10 \%$ & $24 \%$ & $34 \%$ & $26 \%$ \\
Accounting and finance & $0 \%$ & $0 \%$ & $0 \%$ & $0 \%$ \\
Advertising and marketing & $0 \%$ & $0 \%$ & $0 \%$ & $0 \%$ \\
Other services & $0 \%$ & $0 \%$ & $0 \%$ & $0 \%$ \\
Retail and wholesale trade & $0 \%$ & $100 \%$ & & $8 \%$ \\
Transport & $0 \%$ & $0 \%$ & & $0 \%$ \\
Mining and quarrying & $50 \%$ & $0 \%$ & $83 \%$ & $55 \%$ \\
Auto and auto components & $17 \%$ & $19 \%$ & $21 \%$ & $20 \%$ \\
Other transport equipment & $40 \%$ & $56 \%$ & $63 \%$ & $55 \%$ \\
\hline & & & & \\
ALL sectors & $8 \%$ & $25 \%$ & $51 \%$ & $31 \%$ \\
& & & &
\end{tabular}


FIGURE 1

CAPITAL / LABOR RATIO BY COUNTRY




FIGURE 2

\section{CAPITAL / LABOR RATIO BY INDUSTRY}

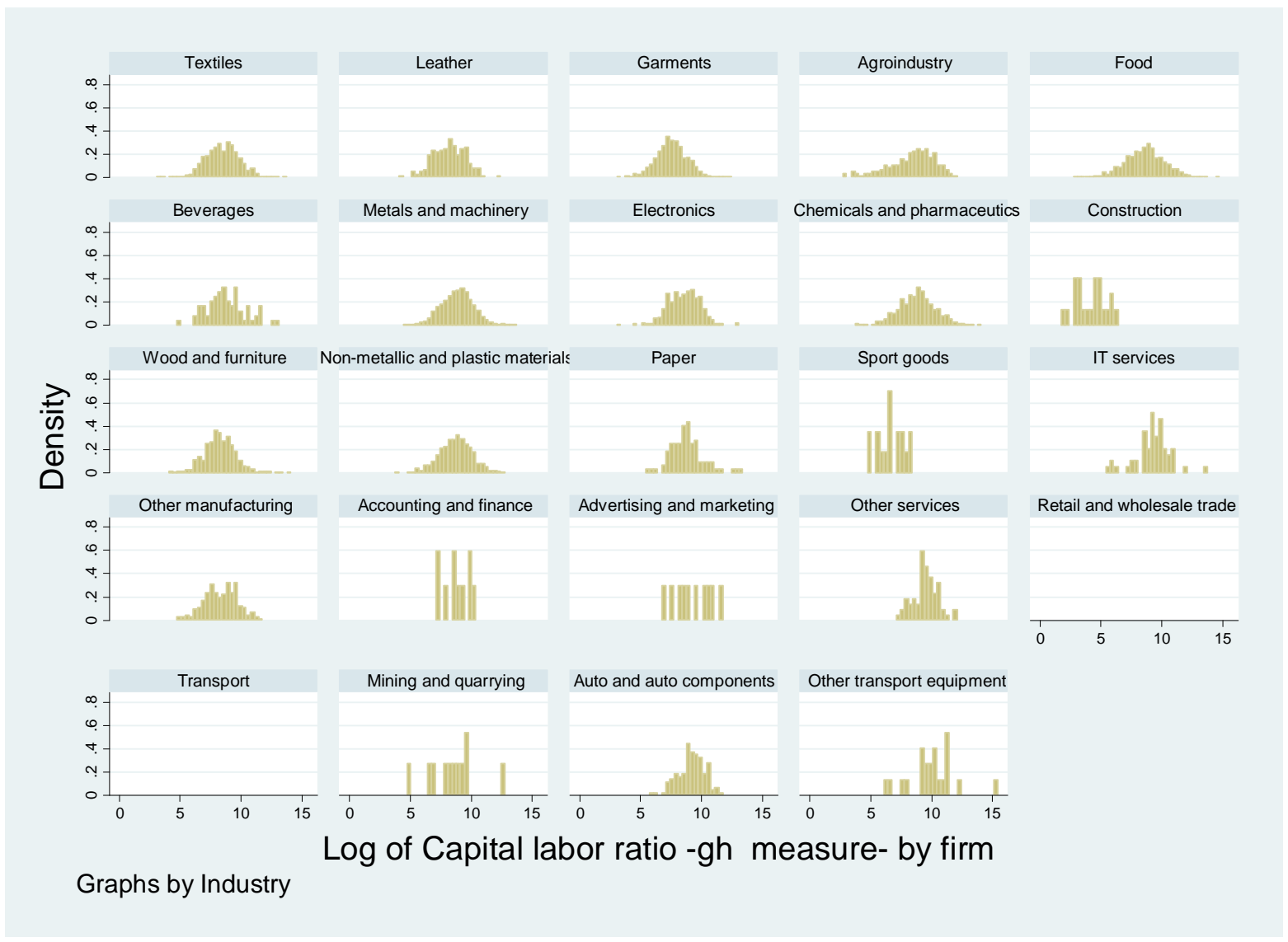


Table 3

The effect of comparative advantage and productivity on the probability of export

Dependent variable: probability of export

\begin{tabular}{|c|c|c|c|c|c|c|c|}
\hline & (1) & (2) & (3) & (4) & (5) & (6) & (7) \\
\hline Log of sales & $\begin{array}{l}0.088 \\
(0.000)^{* * *}\end{array}$ & & & $\begin{array}{l}0.087 \\
(0.000)^{* * *}\end{array}$ & & $\begin{array}{l}0.045 \\
(0.000)^{* * *}\end{array}$ & $\begin{array}{l}0.040 \\
(0.000)^{* * *}\end{array}$ \\
\hline Log of employment & & $\begin{array}{l}0.130 \\
(0.000)^{* * *}\end{array}$ & & & $\begin{array}{l}0.130 \\
(0.000)^{* * *}\end{array}$ & $\begin{array}{l}0.080 \\
(0.000)^{* * *}\end{array}$ & $\begin{array}{l}0.087 \\
(0.000)^{* * *}\end{array}$ \\
\hline Comparative advantage & & & $\begin{array}{l}0.088 \\
(0.000)^{* * *}\end{array}$ & $\begin{array}{l}0.085 \\
(0.000)^{* * *}\end{array}$ & $\begin{array}{l}0.093 \\
(0.000)^{* * *}\end{array}$ & $\begin{array}{l}0.089 \\
(0.000)^{* * *}\end{array}$ & $\begin{array}{l}0.089 \\
(0.000)^{* * *}\end{array}$ \\
\hline Log capital labor ratio & & & & & & & $\begin{array}{l}0.012 \\
(0.016)^{* *}\end{array}$ \\
\hline Observations & 7742 & 7822 & 7822 & 7742 & 7822 & 7742 & 7742 \\
\hline Pseudo R2: & 0.254 & 0.260 & 0.165 & 0.258 & 0.265 & 0.275 & 0.276 \\
\hline
\end{tabular}

* significant at 10 percent; ${ }^{* *}$ significant at 5 percent; ${ }^{* * *}$ significant at 1 percent.

Robust $p$ values in parentheses.

Regressions include country and sector fixed effects

Coefficients reflect marginal effects

Table 4

The effect of comparative advantage and productivity on the probability of export

Dependent variable: probability of export

(errors clustered by country-industry)

\begin{tabular}{|c|c|c|c|c|c|c|c|}
\hline & $(1)$ & $(2)$ & (3) & (4) & (5) & (6) & (7) \\
\hline Log of sales & $\begin{array}{l}0.088 \\
(0.000)^{* * *}\end{array}$ & & & $\begin{array}{l}0.087 \\
(0.000)^{* * *}\end{array}$ & & $\begin{array}{l}0.045 \\
(0.000)^{* * *}\end{array}$ & $\begin{array}{l}0.040 \\
(0.000)^{* * *}\end{array}$ \\
\hline Log of employment & & $\begin{array}{l}0.130 \\
(0.000)^{* * *}\end{array}$ & & & $\begin{array}{l}0.130 \\
(0.000)^{* * *}\end{array}$ & $\begin{array}{l}0.080 \\
(0.000)^{* * *}\end{array}$ & $\begin{array}{l}0.087 \\
(0.000)^{* * *}\end{array}$ \\
\hline Comparative advantage & & & $\begin{array}{l}0.088 \\
(0.003)^{* * *}\end{array}$ & $\begin{array}{l}0.085 \\
(0.003)^{* * *}\end{array}$ & $\begin{array}{l}0.093 \\
(0.000)^{* * *}\end{array}$ & $\begin{array}{l}0.089 \\
(0.001)^{* * *}\end{array}$ & $\begin{array}{l}0.089 \\
(0.001)^{* * *}\end{array}$ \\
\hline Log capital labor ratio & & & & & & & $\begin{array}{l}0.012 \\
(0.089)^{*}\end{array}$ \\
\hline Observations & 7742 & 7822 & 7822 & 7742 & 7822 & 7742 & 7742 \\
\hline Pseudo R2: & 0.254 & 0.260 & 0.165 & 0.258 & 0.265 & 0.275 & 0.276 \\
\hline
\end{tabular}

* significant at 10 percent; ${ }^{* *}$ significant at 5 percent; ${ }^{* * *}$ significant at 1 percent.

Robust $p$ values in parentheses.

Regressions include country and sector fixed effects

Coefficients reflect marginal effects 
Table 5

The effect of comparative advantage, productivity, and networks on the probability of exporting

\begin{tabular}{|c|c|c|c|c|c|c|c|c|c|c|c|c|}
\hline \multicolumn{13}{|c|}{ Dependent variable: probability of export } \\
\hline & $(1)$ & (2) & (3) & (4) & (5) & (6) & (7) & (8) & (9) & (10) & (11) & (12) \\
\hline \multirow[t]{2}{*}{ Comparative advantage } & 0.089 & 0.094 & 0.080 & 0.086 & 0.089 & 0.093 & 0.065 & 0.097 & 0.087 & 0.097 & 0.101 & 0.102 \\
\hline & $(0.000)^{* * *}$ & $(0.000)^{* * *}$ & $(0.000)^{* * *}$ & $(0.000)^{* * *}$ & $(0.000)^{* * *}$ & $(0.000)^{* * *}$ & $(0.000)^{* * *}$ & $(0.000)^{* * *}$ & $(0.000)^{* * *}$ & $(0.000)^{* * *}$ & $(0.000)^{* * *}$ & $(0.000)^{* * *}$ \\
\hline \multirow[t]{2}{*}{ Log of sales } & 0.045 & 0.046 & 0.038 & 0.040 & 0.035 & 0.041 & 0.048 & 0.048 & 0.045 & 0.046 & 0.053 & 0.052 \\
\hline & $(0.000)^{* * *}$ & $(0.000)^{* * *}$ & $(0.000)^{* * *}$ & $(0.000)^{* * *}$ & $(0.000)^{* * *}$ & $(0.000)^{* * *}$ & $(0.000)^{* * *}$ & $(0.000)^{* * *}$ & $(0.000)^{* * *}$ & $(0.000)^{* * *}$ & $(0.000)^{* * *}$ & $(0.000)^{* * *}$ \\
\hline \multirow[t]{2}{*}{ Log of employment } & 0.080 & 0.083 & 0.111 & 0.079 & 0.073 & 0.078 & 0.061 & 0.083 & 0.087 & 0.095 & 0.082 & 0.068 \\
\hline & $(0.000)^{* * *}$ & $(0.000)^{* * *}$ & $(0.000)^{* * *}$ & $(0.000)^{* * *}$ & $(0.000)^{* * *}$ & $(0.000)^{* * *}$ & $(0.000)^{* * *}$ & $(0.000)^{* * *}$ & $(0.000)^{* * *}$ & $(0.000)^{* * *}$ & $(0.000)^{* * *}$ & $(0.000)^{* * *}$ \\
\hline \multirow[t]{2}{*}{ Foreign financing } & & 0.003 & & & & & & & & & & 0.003 \\
\hline & & $(0.000)^{* * *}$ & & & & & & & & & & $(0.026)^{* *}$ \\
\hline \multirow[t]{2}{*}{ Foreign joint venture } & & & 0.133 & & & & & & & & & 0.131 \\
\hline & & & $(0.000)^{* * *}$ & & & & & & & & & $(0.002)^{* * *}$ \\
\hline \multirow[t]{2}{*}{ Foreign participation } & & & & 0.002 & & & & & & & & 0.002 \\
\hline & & & & $(0.000)^{* * *}$ & & & & & & & & $(0.000)^{* * *}$ \\
\hline \multirow[t]{2}{*}{ Firm uses email } & & & & & 0.201 & & & & & & & 0.134 \\
\hline & & & & & $(0.000)^{* * *}$ & & & & & & & $(0.000)^{* * *}$ \\
\hline \multirow[t]{2}{*}{ Firm has website } & & & & & & 0.131 & & & & & & 0.073 \\
\hline & & & & & & $(0.000)^{* * *}$ & & & & & & $(0.007)^{* * *}$ \\
\hline \multirow[t]{2}{*}{ Firm part of chamber of commerce } & & & & & & & 0.097 & & & & & 0.127 \\
\hline & & & & & & & $(0.000)^{* * *}$ & & & & & $(0.000)^{* * *}$ \\
\hline \multirow[t]{2}{*}{ Time spent with gov't regulations } & & & & & & & & 0.001 & & & & 0.002 \\
\hline & & & & & & & & $(0.011)^{* *}$ & & & & $(0.030)^{* *}$ \\
\hline \multirow[t]{2}{*}{ State participation } & & & & & & & & & -0.002 & & & -0.004 \\
\hline & & & & & & & & & $(0.000)^{* * *}$ & & & $(0.010)^{* *}$ \\
\hline \multirow[t]{2}{*}{ Unionization } & & & & & & & & & & -0.001 & & 0.001 \\
\hline & & & & & & & & & & $(0.000)^{* * *}$ & & $(0.180)$ \\
\hline Years since creation & & & & & & & & & & & 0.003 & 0.003 \\
\hline & & & & & & & & & & & $(0.000)^{* * *}$ & $(0.000)^{* * *}$ \\
\hline Observations & 7742 & 7325 & 5699 & 7695 & 7371 & 7253 & 5922 & 5991 & 7695 & 7246 & 6817 & 2356 \\
\hline Pseudo R2: & 0.275 & 0.276 & 0.250 & 0.287 & 0.294 & 0.281 & 0.299 & 0.272 & 0.280 & 0.273 & 0.274 & 0.281 \\
\hline
\end{tabular}

*significant at 10 percent; ${ }^{* *}$ significant at 5 percent; ${ }^{* * *}$ significant at 1 percent.

Robust $\mathrm{p}$ values in parentheses.

Regressions include country and sector fixed effects

Coefficients reflect marginal effects 
Table 6

The effect of comparative advantage, productivity, and networks on the probability of exporting

Dependent variable: probability of export

(errors clustered by country-industry)

\begin{tabular}{|c|c|c|c|c|c|c|c|c|c|c|c|c|}
\hline & $(1)$ & (2) & (3) & (4) & $(5)$ & (6) & (7) & (8) & (9) & (10) & (11) & (12) \\
\hline \multirow[t]{2}{*}{ Comparative advantage } & 0.089 & 0.094 & 0.080 & 0.086 & 0.089 & 0.093 & 0.065 & 0.097 & 0.087 & 0.097 & 0.101 & 0.102 \\
\hline & $(0.001)^{* * *}$ & $(0.001)^{* * *}$ & $(0.002)^{* * *}$ & $(0.001)^{* * *}$ & $(0.001)^{* * *}$ & $(0.001)^{* * *}$ & $(0.038)^{* *}$ & $(0.003)^{* * *}$ & $(0.001)^{* * *}$ & $(0.000)^{* * *}$ & $(0.000)^{* * *}$ & $(0.004)^{* * *}$ \\
\hline \multirow[t]{2}{*}{ Log of sales } & 0.045 & 0.046 & 0.038 & 0.040 & 0.035 & 0.041 & 0.048 & 0.048 & 0.045 & 0.046 & 0.053 & 0.052 \\
\hline & $(0.000)^{* * *}$ & $(0.000)^{* * *}$ & $(0.000)^{* * *}$ & $(0.000)^{* * *}$ & $(0.000)^{* * *}$ & $(0.000)^{* * *}$ & $(0.000)^{* * *}$ & $(0.000)^{* * *}$ & $(0.000)^{* * *}$ & $(0.000)^{* * *}$ & $(0.000)^{* * *}$ & $(0.000)^{* * *}$ \\
\hline \multirow[t]{2}{*}{ Log of employment } & 0.080 & 0.083 & 0.111 & 0.079 & 0.073 & 0.078 & 0.061 & 0.083 & 0.087 & 0.095 & 0.082 & 0.068 \\
\hline & $(0.000)^{* * *}$ & $(0.000)^{* * *}$ & $(0.000)^{* * *}$ & $(0.000)^{* * *}$ & $(0.000)^{* * *}$ & $(0.000)^{* * *}$ & $(0.000)^{* * *}$ & $(0.000)^{* * *}$ & $(0.000)^{* * *}$ & $(0.000)^{* * *}$ & $(0.000)^{* * *}$ & $(0.000)^{* * *}$ \\
\hline \multirow{2}{*}{ Foreign financing } & & 0.003 & & & & & & & & & & 0.003 \\
\hline & & $(0.000)^{* * *}$ & & & & & & & & & & $(0.036)^{* *}$ \\
\hline \multirow[t]{2}{*}{ Foreign joint venture } & & & 0.133 & & & & & & & & & 0.131 \\
\hline & & & $(0.000)^{* * *}$ & & & & & & & & & $(0.002)^{* * *}$ \\
\hline \multirow[t]{2}{*}{ Foreign participation } & & & & 0.002 & & & & & & & & 0.002 \\
\hline & & & & $(0.000)^{* * *}$ & & & & & & & & $(0.000)^{* * *}$ \\
\hline \multirow[t]{2}{*}{ Firm uses email } & & & & & 0.201 & & & & & & & 0.134 \\
\hline & & & & & $(0.000)^{* * *}$ & & & & & & & $(0.002)^{* * *}$ \\
\hline \multirow[t]{2}{*}{ Firm has website } & & & & & & 0.131 & & & & & & 0.073 \\
\hline & & & & & & $(0.000)^{* * *}$ & & & & & & $(0.005)^{* * *}$ \\
\hline \multirow[t]{2}{*}{ Firm part of chamber of commerce } & & & & & & & 0.097 & & & & & 0.127 \\
\hline & & & & & & & $(0.000)^{* * *}$ & & & & & $(0.000)^{* * *}$ \\
\hline \multirow[t]{2}{*}{ Time spent with gov't regulations } & & & & & & & & 0.001 & & & & 0.002 \\
\hline & & & & & & & & $(0.012)^{* *}$ & & & & $(0.032)^{* *}$ \\
\hline \multirow[t]{2}{*}{ State participation } & & & & & & & & & -0.002 & & & -0.004 \\
\hline & & & & & & & & & $(0.001)^{* * *}$ & & & $(0.003)^{* * *}$ \\
\hline \multirow[t]{2}{*}{ Unionization } & & & & & & & & & & -0.001 & & 0.001 \\
\hline & & & & & & & & & & $(0.000)^{* * *}$ & & $(0.222)$ \\
\hline Years since creation & & & & & & & & & & & 0.003 & 0.003 \\
\hline Observations & 7742 & 7325 & 5699 & 7695 & 7371 & 7253 & 5922 & 5991 & 7695 & 7246 & $\begin{array}{l}(0.000)^{* * *} \\
6817\end{array}$ & $\begin{array}{l}(0.000)^{* * *} \\
2356\end{array}$ \\
\hline Pseudo R2: & 0.275 & 0.276 & 0.250 & 0.287 & 0.294 & 0.281 & 0.299 & 0.272 & 0.280 & 0.273 & 0.274 & 0.281 \\
\hline
\end{tabular}

* significant at 10 percent; ${ }^{* *}$ significant at 5 percent; ${ }^{* * *}$ significant at 1 percent.

Robust $p$ values in parentheses.

Regressions include country and sector fixed effects

Coefficients reflect marginal effects 
Appendix Table

Summary Statistics

\begin{tabular}{|c|c|c|c|c|c|}
\hline Variable & Obs & Mean & Std. Dev. & Min & Max \\
\hline Firm is an exporter ${ }^{(1)}$ & 7742 & 0.32 & 0.47 & 0.00 & 1.00 \\
\hline Log of sales & 7742 & 14.07 & 2.60 & -2.17 & 24.56 \\
\hline Log of employment & 7742 & 4.29 & 1.54 & 0.69 & 9.85 \\
\hline Firm is in comparative advantage industry ${ }^{(1)}$ & 7742 & 0.53 & 0.50 & 0.00 & 1.00 \\
\hline Log of KL ratio & 7742 & 8.48 & 1.49 & 2.78 & 15.11 \\
\hline Foreign financing ${ }^{(2)}$ & 7325 & 1.05 & 7.59 & 0.00 & 100.00 \\
\hline Firm is in a joint venture with a foreign partner ${ }^{(1)}$ & 5699 & 0.07 & 0.26 & 0.00 & 1.00 \\
\hline Foreign participation ${ }^{(3)}$ & 7695 & 10.14 & 27.81 & 0.00 & 100.00 \\
\hline Firm uses email ${ }^{(1)}$ & 7371 & 0.62 & 0.49 & 0.00 & 1.00 \\
\hline Firm has website ${ }^{(1)}$ & 7253 & 0.35 & 0.48 & 0.00 & 1.00 \\
\hline Firm belongs to a chamber of commerce ${ }^{(1)}$ & 5922 & 0.67 & 0.47 & 0.00 & 1.00 \\
\hline Time spent with gov't regulations ${ }^{(4)}$ & 5991 & 8.61 & 13.48 & 0.00 & 100.00 \\
\hline State participation ${ }^{(5)}$ & 7695 & 5.81 & 21.57 & 0.00 & 100.00 \\
\hline Unionization ${ }^{(6)}$ & 7246 & 19.06 & 35.30 & 0.00 & 100.00 \\
\hline Year firm began operations & 6818 & 1983 & 18 & 1838 & 2004 \\
\hline
\end{tabular}

(1) Dummy variable: 1 if the firm does, 0 Otherwise.

(2) Percentage finance for working capital: foreign-owned banks;

(3) Percentage of firm owned by foreign private sector;

(4) Percentage of senior management's time spent dealing with government regulations;

(5) Percentage of firm owned by the state

(6) Percentage of labor force unionized. 